"Conceptualizing innovation management development through organizational learning in the public service: any lessons for developing states?"

\begin{tabular}{ll} 
AUTHORS & $\begin{array}{l}\text { Lere Amusan } \text { https://orcid.org/0000-0001-6403-5008 } \\
\text { Oluwayemisi Adebola Oyekunle }\end{array}$ \\
& $\begin{array}{l}\text { Lere Amusan and Oluwayemisi Adebola Oyekunle (2016). Conceptualizing } \\
\text { innovation management development through organizational learning in the } \\
\text { public service: any lessons for developing states?. Problems and Perspectives in } \\
\text { MRTICLE INFO }\end{array}$ \\
\hline MOnagement, $14(3-1), 266-275$. doi:10.21511/ppm.14(3-1).2016.13
\end{tabular}

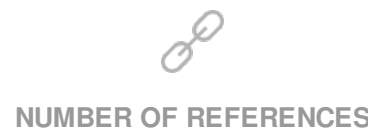

0
NUMBER OF FIGURES

0

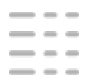

NUMBER OF TABLES

0

(C) The author(s) 2023. This publication is an open access article. 
Lere Amusan (South Africa), Oluwayemisi Adebola Oyekunle (South Africa)

\title{
Conceptualizing innovation management development through organizational learning in the public service: any lessons for developing states?
}

\begin{abstract}
The present economic realities, the effects of globalization, the thirst for innovation and the public's demand for improved services have led many developing states to review their approaches to service delivery. Most public service managers and professionals spend most of their time dealing with the day-to-day pressures of delivering services, operating and reporting to senior managers, legislators and agencies. They have little or no time to think about innovation, which would ease the pressures and burdens of service delivery. The intention of this paper is to point out the fact that capacity building is the bedrock of new public management development. This paper proposes that innovation management could be used as a form of organizational learning capability in challenging the maze of diplomacy and negotiation with experienced multinational extractive industries for the benefit of developing states. This could be achieved through excellent public investments and nurturing capability, from which they execute effective innovation processes, leading to new service innovations and processes, and superior service performance results. To achieve this objective, extensive literature on innovation management and organizational learning was consulted and the need for future research. In trying to unpack the discussion in the paper, the New Public Management Theory (NPMT), which is a pro-private sectors human resources management is proposed, though other available theoretical positions are explored taking into consideration the lapses entrenched in NPMT.
\end{abstract}

Keywords: innovation, NPMT, learning culture, public management, developing states, development.

JEL Classification: $\mathrm{O} 10$.

\section{Introduction}

In the present fast-tracking changing environment, bureaucrats are contending with the challenges of improving their performance in order to take advantage of new public management (NPM) perspective in service delivery, and build a competitive edge over the private sector (Drezner, 2004, p. 26). The number of perspectives on how public sectors can develop organizational capabilities in order to achieve competitive advantage has obtained considerable attention in innovation management. Public firms that integrate technical and managerial innovations into their organizational structures will be able to face environmental challenges and uncertainties in enhancing superior performance. Hult, Hurley and Knight (2004) found in their study that firms, which show a greater ability to innovate, are prone to successful environmental changes and have a greater capacity to develop skills that enable them to gain competitive advantage.

The need for innovation arises from the understanding that competence, skills, knowledge, product services and branding that are not competitive compared with the private organization may lead to poor services. The end-result of this in the $21^{\text {st }}$ century of the ultracapitalism amounts to incessant protests and political instability (Amusan, 2015; Drucker, 1992).

(C) Lere Amusan, Oluwayemisi Adebola Oyekunle, 2016.

Lere Amusan, Ph.D., Professor, Department of Politics and International Relations, North West University, Mafikeng, South Africa. Oluwayemisi Adebola Oyekunle, Ph.D. Student, Faculty of Management Sciences in Business school, Tshwane University of Technology, South Africa.
As companies become increasingly focused on innovation, performance hurdles for success also increase considerably, most especially if it is a "sustaining innovation" (Mezue et al., 2015). This will enhance vibrancy and competitiveness. Therefore, escalating the level of commitment to innovation is necessary in order to stay in the same place (Lawson and Samson, 2001). Many have struggled out with ways to improve their performance through learning since1990 when Peter Senge published his pioneering book The Fifth Discipline: The Art and Practice of the Learning. Even though Peter Senge's description draws mainly from experiences and insights gained in the private sector, his work has inspired many working in the public sector. This brings about the need for NPMT as an instrument of our discussion.

From where do public services managers actually "learn"? Private sector experience, overseas examples, personal contacts or local networks are all possible sources of learning (Fenwick and Mcmillan, 2005). The private sector was initially held up as the model for the public service to emulate, "seen as a panacea" at the time (as in the era of Compulsory Competitive Tendering (CCT)) (Fenwick and Mcmillan, 2005). However, as pointed out in Fenwick and Mcmillan, things have "moved on" and the private sector is no longer the only model on offer.

This paper provides an outline of management procedures for public managers on how the process of innovation can be managed, standardized and replicated within government departments. Based on a broad examination of literature on innovation 
management, it is evident that representation of innovation capability is evolving. The established literature on organizational learning is currently considered specifically in the light of modernization agenda in public services. The paper reveals that successful innovation management contains foundation elements and processes within the government establishments. Thus, high performing innovators will be able to engage in this innovation at high capability to achieve outstanding performance. To unpack the challenges that lie ahead, this paper is divided into six parts as follows. Part 1 is the general introduction; part 2 examines the concept of innovation and how it can improve the public sector in developing states through NPMT; part 3 interrogates public sector innovation management process; part 4 focuses on learning culture; the penultimate section examines organizational learning; and part 6 is the conclusion and possible recommendations.

\section{Innovation in public management}

Innovation in public sectors implies improving on existing services and processes, finding new ways and abandoning the old. It is an improvement on the existing products or processes that involve new ideas through development and adapting of new technology or new ways of doing business (Mathews, 2003). It is a "process of bringing any new, problem-solving idea into use", to a more resourceful approach. It can also be viewed as a process whereby new ideas are transformed through economic activity into sustainable value-creating outcomes" (Kanter, 1983; Livingstone, 2000). Innovation in an organization increases performance and growth through improvements. It is not just about having good ideas, but also, it is a team effort where all areas of an organization contribute positively towards its actualization (Grier, 2014). Microsoft Corporation (2009) states that:

To facilitate the innovation process effectively, organizations need a solution that allows them to manage innovation in an objective, strategic, and scalable manner. Because organizations often lack the resources necessary to act on all contributed ideas, they must manage innovation through a systematic process that facilitates the selection of optimal ideas, which have the highest strategic value.

Different forms of innovation abound. Technological, process, service, strategic and managerial innovations are the common ones, as pointed out by Welles (2011). This includes innovations in products, services, processes, technologies, practices and structures. Therefore, it is the generation and/or acceptance of ideas, processes, products, services or technologies that the relevant adopting unit perceives as new (Garcia and Calantone, 2002).
Current research on innovation increasingly investigates its relation with organizational learning (Welles, 2011). In the last decade, innovation has become a catch cry and so, and has been encouraged to be part of the innovation explosion' (Quinn, Jordan and Zien, 1997). Hence, 'innovate or die' (Peters, 1990). Kline and Rosenberg (1986) add that innovation is a complex process, and the ability to know the potential of an innovation is not an easy process.

The public service in developing states is innovating at different rates. Mathews (2003) classifies firms along a range as: static, innovative, learning and selfgenerating firms based on whether or not they were involved in systematic innovation, whether the firm could extend to new markets, had the ability to adapt to changing environmental conditions, or the ability to strategically reposition itself in the industry (Gooderham et al., 2013). Mathew's criteria are summarized in the Table below. A firm can operate at different levels with respect to different innovative capacities. Little (2001) also explains the levels of innovativeness and discusses the possible forms of organizational learning levels of innovation in firms, all tabulated below:

Table 1. Mathew's criteria for innovativeness

\begin{tabular}{|l|l|}
\hline \multicolumn{1}{|c|}{ Levels of innovativeness } & \multicolumn{1}{|c|}{ Organizational descriptors } \\
\hline Level 0 - the static firm & $\begin{array}{l}\text { Not involved in systematic innovation, but may } \\
\text { have a stable market position, while present } \\
\text { conditions persist. }\end{array}$ \\
\hline $\begin{array}{l}\text { Level 1 - the innovating } \\
\text { firm }\end{array}$ & $\begin{array}{l}\text { Able to produce innovations serving known } \\
\text { markets efficiently and effectively. }\end{array}$ \\
\hline Level 2 - the learning firm & $\begin{array}{l}\text { Adapting to a changing environment; being able to } \\
\text { question existing routines and norms and develop } \\
\text { new ones; double-loop learning. }\end{array}$ \\
\hline $\begin{array}{l}\text { Level 3 - the self- } \\
\text { regenerating firm }\end{array}$ & $\begin{array}{l}\text { Displays strategic re-positioning: able to question, } \\
\text { change/re-shape the industry it is in; triple loop } \\
\text { learning. Visionary leadership and long-term } \\
\text { commitment are key. }\end{array}$ \\
\hline
\end{tabular}

Source: Little (2001).

Researches on innovation in the public service have found that successful innovation is characterized by the correct anticipation of public needs, detailed knowledge of the general environmental framework, and intelligent application of technology, where all the internal and external resources of an organization need integration.

\subsection{Innovation challenges in the developing areas.} The process of innovation consists of several challenges such as:

- difficulty in investing in the right ideas in the right markets with the right resources;

- no structures, processes in place to drive transparency, metric or cross-functional collaboration;

- no ideal method to measure innovation; 
- difficulty in selecting the right ideas;

- limited opportunity for all employees to contribute;

- lack of coordination and customer insight; and

- few avenues with which to socialize ideas with a wide audience.

These challenges must be tackled effectively in order to meet the organization's needs in the form of:

- accelerating growth;

- increasing competitiveness; and

- empowering all employees to contribute.

To address all these challenges, some possible solutions hae been proposed by Microsoft multinational corporations as follows:

- strategize;

- capture;

- formulate;

- evaluate;

- define;

- select.

In order to achieve a positive result in any organization, there should be a public sectors innovation, which is usually absent in many developing states as discussed below.

1.2. Public sector innovation management process. Cohen and Eimicke (1996) define public sector innovation management as the development of new policy designs and new standard operating procedures by public organizations to address public policy problems. Thus, the linkage between vision, strategy and innovation is important to effective innovation management (Lawsom and Samson, 2000). The capacity of public organizations to innovate depends on different factors such as the organization's vision and strategy, a sound competency base, creativity and idea management, and process, culture and climate and intelligence (Little, 2001). Adams, Bessant and Phelps (2006), in their contribution to this discourse, view innovation management process in line with the different categories analyzed in the Table 2 below:

Table 2. Innovation management processes

\begin{tabular}{|l|l|}
\hline Inputs management & $\begin{array}{l}\text { The resourcing of innovation activities, including } \\
\text { financial, human, and physical resources (i.e., } \\
\text { facilities). }\end{array}$ \\
\hline Knowledge management & $\begin{array}{l}\text { Obtaining and communicating ideas and } \\
\text { information that underlie innovation competencies. }\end{array}$ \\
\hline Innovation strategy & $\begin{array}{l}\text { Innovation goals including new products and market } \\
\text { development goals, and resource allocation } \\
\text { decisions. }\end{array}$ \\
\hline $\begin{array}{l}\text { Organizational structure } \\
\text { and culture }\end{array}$ & $\begin{array}{l}\text { Dimensions of culture and structure that have been } \\
\text { identified to differentiate between innovation and } \\
\text { non-innovative organizations. }\end{array}$ \\
\hline Portfolio management & $\begin{array}{l}\text { Managing and allocating resources in the } \\
\text { innovation process by making strategic, } \\
\text { technological and resource choices that govern } \\
\text { project selection. }\end{array}$ \\
\hline
\end{tabular}

\begin{tabular}{|l|l|}
\hline Project management & $\begin{array}{l}\text { Processes that turn inputs into a marketable } \\
\text { innovation, involving the separation of the product } \\
\text { development into stages. }\end{array}$ \\
\hline Commercializing & $\begin{array}{l}\text { Launch and implementation processes of new } \\
\text { products and services into the market. }\end{array}$ \\
\hline
\end{tabular}

Source: Adams, Bessant and Phelps (2006).

Through the engagement of the different categories mentioned above, public sectors in developing states will be able to evaluate their innovation activity, weaknesses and potential improvements. These different categories also give a better understanding of the complexity of the innovation process worth taking into consideration (Adams, Bessant and Phelps, 2006).

In order to motivate innovation management process of interaction through collaboration to public innovation, social and political actors need to implement some form of collaborative leadership and innovation management. Therefore, management of processes of collaborative innovation can be rendered either by trained facilitators or by related leaders who are connected to and acquainted with stakeholders in the collaborative arena.

Research on innovation in public, largely examines innovation in relation to organizational learning. Thus, innovation enables the public sector to gain competitive advantage over the private sector by improving existing services and developing new ones in a dynamic society. It is a broad and complex process, which involves different stages and management processes (Welles, 2011), as shown below.

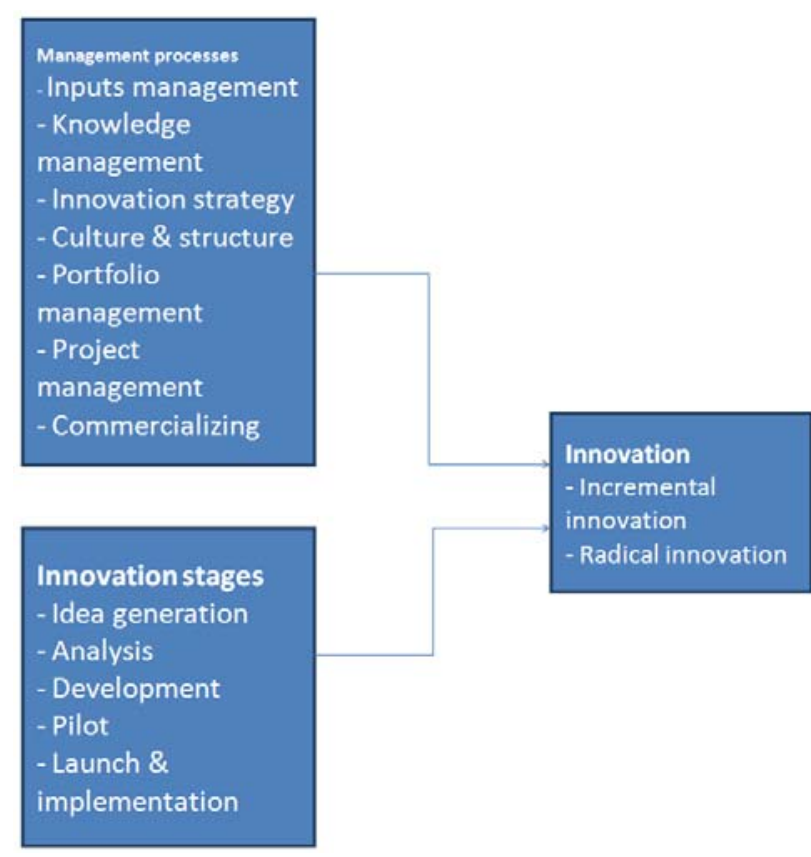

Fig. 1. Stages and management processes

Appropriate innovation seeks to be "the best of the best" and employees have clarity of purpose. It aims at doing things differently in order to achieve functional and dynamic goals (Lawson and Samson, 
2001, p. 389). Thus, the significant evaluation of the innovative capacity of the public sector is not completely mistaken. With regard to the public sector, there is a lot of uncertainty considering the capacity for innovating public policies, organizations and services.

Many people, especially those employed in the private sector, consider the public sector as a slowmoving bureaucracy characterized by red-tapes, inertia and stalemates (Halvorsen and Torfing, 2012). Halvorsen, Hauknes and Roste (2005) consider stability as the primary objective of public bureaucracy. They further posit that the thick layer of formal rules, the multi-layered hierarchies, the organizational silos, the lack of economic incentives and the divided political leadership at the top of public bureaucracies tend to stifle public innovation and by extension, technological innovation (Dessler et al., 2011, pp. 606-607). Also of concern is the problem associated with spoils recruitment into departments and parastatals in the form of affirmative action as against meritocracy, as proposed by the neo-Wilsonian (NPMT) school of thought (Adamolekun, 1986, p. 18; Mello, 2013, p. 54). Though this practice is not limited to Third World States (TWSs), it is also prevalent in emerging economies such as China and Russia. This is to ensure political stability, continuity, loyalty and implementation of ruling party policies religiously (Amusan, 2015). It is also a means "to eliminate systematic bias against members of underrepresented groups by requiring an organization 'to take proactive steps towards ensuring that the demographic characteristics of its workforce are consistent with the demographic characteristics of the labor markets in which it recruits" (Greenhaus et al., 2010, p. 336). This position is parallel to the Wilsonian approach of anonymity, permanency and neutrality/impartiality.

Gary Dessler et al. (2011) and Paul N. Gooderham et al., (2013) believe that, as we enter the 21st century, the society and the economy have been changing rapidly in response to new technologies and have facilitated greater exchange which, in turn, facilitates economic and social interdependency. This accelerated rate of change has challenged the traditional bureaucratic form of organization to develop new methods for rapidly modifying organizational strategies (Cohen and Eimicke, 1996). Therefore, public organizations are being challenged to learn and embrace constant changes and innovation in their management systems.

However, it seems clear that the public sector is far more dynamic and innovative than its name. Looking back and comparing the public sector in TWSs, it is clear that there are many changes towards private sector management strategies, as captured by the
NPMT. Various public innovations, which have taken place against all odds, serve to remind us that regardless of the many barriers to public innovation, there are some important developments towards innovative ideas in the public sector.

Successful innovation requires a clear articulation of a common vision and the firm expression of the strategic direction. This is a critical step in institutionalizing innovation (Lawson and Samson, 2001). As a result, public organizations' innovation is more than just benchmarking. This, therefore, provides a background for public service managers showing that the process of innovation can be managed, organized and replicated globally despite institutional challenges, as discussed by Michael Trebilcock and Mariana Prado (2011).

Public service shaped by legislation, and consequences of this are the perception that the public service lacks innovation and creativity, and results in poor service delivery or no delivery at all. There are other reasons why government institutions are opting for alternative methods of service delivery, such as outsourcing strategy to reduce complacency and encouraging innovation among employees and rebuilding trust in the public service (Zubani, 2011). At the same time, outsourcing continues to generate arguments among state-centric students of social sciences and humanities. The state, according to Mariana Mazzucato (2015, p. 65), should stick to fixing market failures...and outsourced key jobs to the private sector. But that trend often rids them (states) of the knowledge necessary for devising a smart strategy for investing in innovation and makes it harder to attract top talent...the less big thinking a government does, the less expertise it is able to attract, the worse it performs, and the less big thinking it is allowed to do.

Therefore, creating a learning culture within public organizations will take it one-step beyond just acquiring the skills and the knowledge that it needs to deliver its services (Progressive International Limited, undated; Rabie et al., 2011). It will also empower employees to achieve, dramatically, improved results compared to more traditional organizations, as it enables staff to:

- easily adapt to change;

- actually anticipate change;

- be more responsive to the marketplace;

- generate more energetic, loyal and goal oriented employees; and

- grow through innovation.

In achieving these objectives, attitudes to learning culture should be the cornerstone of public servants. 


\section{Learning culture}

Instituting learning depends on a learning culture. Thornhill and Van Dijk (2003) maintain that a learning culture does not mean sending employees on as many training courses as possible without evaluating the outcomes of these courses. Contrarily, it is a process of identifying, on a continuous basis, those training courses that would satisfy both individual and organizational development needs. In a learning culture, the acquisition of new knowledge and skills is supported by aspects of the organization's environment that encourage surfacing, noticing, gathering, sharing, and applying new knowledge (Garvin, 1993). Learning has a culture that holds learning and innovations jointly with individuals and itself.

A learning culture should sustain learning to ensure the free exchange and flow of information to put expertise where it is needed most. It also ought to encourage individuals to network extensively across organizational boundaries in order to develop their own knowledge and expertise. Supporting commitment to learning and personal development where learning is rewarded and encouraged is equally essential (Thornhill and Van Dijk, 2003). The culture of the whole, the ways in which people communicate with each other, the ways in which people lead are the essential ingredients of learning culture. It also involves evaluation performance, the physical environment of work places and how the knowledge management has impacts on sustaining learning over time (Garvin, 1993). Maccoby (2003) states that, in a learning culture, people take responsibility and support one another, they share experiences and learn from mistakes, as well as successes. Maccoby believes that a learning culture can develop from the top of the organization, because good ideas are heard, acted on and rewarded.

The purpose of creating a learning culture is, therefore, to create an environment where everyone teaches, everyone learns, and everyone enhances his or her exceptional abilities (Progressive International Limited, undated). There is a need to conduct a 'zerobased audit' every three years systematically and put every part of the company on trial. This should focus on every product, service, technology, market and distribution channel, particularly in the service sector through simple "self-audit" of assessment (Drucker, 1992; Corner and Clawson, 2002). In actualizing this, this paper adopts learning culture of ranking each characteristic on a scale of 1 to 5,5 being always yes and 1 being always no, and at the bottom, tally the numbers to determine, if one has more of a prolearning or an anti-learning culture. Circle the items in each category that will require special attention in the coming days, weeks, and years.

\subsection{Learning culture self-audit.}

Table 3. Learning culture self-audit

\begin{tabular}{|c|c|}
\hline Pro-learning culture & Anti-learning culture \\
\hline $\begin{array}{l}\text { People at all levels ask questions and share stories about successes, failures, } \\
\text { and what they have learned }\end{array}$ & $\begin{array}{l}\text { Managers share information on a need-to-know basis. People keep secrets } \\
\text { and do not describe how events really happened }\end{array}$ \\
\hline $\begin{array}{l}\text { Everyone creates, keeps, and propagates stories of individuals who have } \\
\text { improved their own processes }\end{array}$ & Everyone believes they know what to do, and they proceed on this assumption \\
\hline $\begin{array}{l}\text { People take at least some time to reflect on what has happened and what may } \\
\text { happen }\end{array}$ & $\begin{array}{l}\text { Little time or attention is given to understanding lessons learned from the } \\
\text { projects }\end{array}$ \\
\hline People are treated as complex individuals & $\begin{array}{l}\text { People are treated like objects or resources without attention to their } \\
\text { individuality }\end{array}$ \\
\hline Managers encourage continuous experimentation & Employees proceed with work only when they feel certain of the outcome \\
\hline $\begin{array}{l}\text { People are hired and promoted on the basis of their capacity for learning and } \\
\text { adapting to new situations }\end{array}$ & $\begin{array}{l}\text { People are hired and promoted on the basis of their technical expertise as } \\
\text { demonstrated by credentials }\end{array}$ \\
\hline Performance reviews include and pay attention to what people have learned & Performance reviews focus almost exclusively on what people have done \\
\hline $\begin{array}{l}\text { Senior managers participate in training programs designed for new or high- } \\
\text { potential employees }\end{array}$ & Senior managers appear only to "kick off" management training programs \\
\hline $\begin{array}{l}\text { Senior managers are willing to explore their underlying values, assumptions, } \\
\text { beliefs, and expectations }\end{array}$ & $\begin{array}{l}\text { Senior managers are defensive and unwilling to explore their underlying } \\
\text { values, assumptions, beliefs, and expectations }\end{array}$ \\
\hline $\begin{array}{l}\text { Conversations in management meetings are constantly exploring the values, } \\
\text { assumptions, beliefs, and expectations underlying proposals and problems }\end{array}$ & $\begin{array}{l}\text { Conversations tend to move quickly to blaming and scape-goating with little } \\
\text { attention to the process that led to a problem or how to avoid it in the future }\end{array}$ \\
\hline $\begin{array}{l}\text { Customer feedback is solicited, actively examined, and included in the next } \\
\text { operational or planning cycle }\end{array}$ & $\begin{array}{l}\text { Customer feedback is not solicited and is often ignored when it comes in over } \\
\text { the transom }\end{array}$ \\
\hline Managers presume that energy comes in large part from learning and growing & $\begin{array}{l}\text { Managers presume that energy comes from "corporate success," meaning } \\
\text { profits and senior management bonuses }\end{array}$ \\
\hline $\begin{array}{l}\text { Managers think about their learning quotient, that is, their interest in and } \\
\text { capacity for learning new things, and the learning quotient of their employees }\end{array}$ & $\begin{array}{l}\text { Managers think that they know all they need to know and that their employees } \\
\text { do not have the capacity to learn much }\end{array}$ \\
\hline
\end{tabular}

Source: Corner and Clawson (2002). 
The Table above shows a total departure between developed states and the attitudes of developing areas towards innovation. This is due to corruption, cronyism, and conservative culture, lack of transparency and the importation of inappropriate technology into the developing countries (Acemoglu and Robinsons, 2012; Mbeki, 2009).

Maccoby (2003) mentions six rules, which he believes supervisors can follow in order to improve teamwork and develop a learning culture as follows:

1. describe the purpose of the work you and the team are doing;

2. clarify roles and responsibilities;

3. make sure managers and subordinates understand each other's personality;

4. communicate and facilitate communication;

5. make an evaluation of a continuous and honest dialogue rather than a bureaucratic process; and

6. in achieving these objectives, the roles of organizational learning cannot be underestimated. This will ensure continuity and the dynamism of the attributes of innovation in public management.

2.2. Organizational learning. Gill (2010) defines organizational learning as the process of forming and applying collective knowledge to problems and needs. It helps the organization to continuously improve, achieve goals, and attain new possibilities and capacities. It taps into employee aspirations, fuelling commitment and creating the energy to change. This is a process of improving actions because of reflection on new knowledge and understanding, and is an important element in innovation process, as it can help an organization in its capacity to innovate. In all instances, the assumption that learning will improve future performance exists, but the problem emerges around a clear definition of learning and management (Fiol and Lyles, 1985).

An organization learns when its employees are continuously creating, organizing, storing, retrieving, interpreting and applying information (Gill, 2010). Despite all the positive attributes of organization learning model, there are some challenges entrenched in it, as captured by Beeby and Booth (2000). They propose two variables: first, the difficult relationship between individual and organizational learning and, second, the distinction between 'single-loop' and 'double-loop' learning. Single-loop learning denotes the correction of errors and modification of action in pursuit of known existing goals. Double-loop learning means that the learning process itself turned back on goals and assumptions with the possible outcome of organizational transformation (Fenwick and McMillan, 2005). In their efforts to promote organizational learning, many public sectors have applied two approaches: the learning loop model of Chris Argyris and Donald Schön, and the learning organization model of Peter Senge. Argyris and Schön (1978) characterized organizational learning in terms of a three-level evolutionary model consisting of:

- single-loop learning, which is in line with explicit practices, policies and norms of behavior. Learning involves identifying and correcting deviations, and variances from these standards;

- double-loop learning, which involves reflection on the appropriateness of fundamental practices, policies and norms. This approach tackles the basic aspects of an organization, in order that the same things are not done in response to changing contexts; and

- triple-loop learning, which stands for the highest form of organizational self-examination. It entails questioning the entire rationale of an organization, and can result in radical transformations in internal structure, culture and practices, as well as in the external context.

Peter M Senge (1990) identifies five disciplines of a learning culture that contribute to building a strong learning organization. These essentials are:

- personal mastery - create an environment that promotes personal and organizational goals to be developed and accomplished in partnership;

- mental models - recognize that a person's inner picture of their environment will influence their decisions and behavior;

- shared vision - create a common sense of purpose by developing shared images of the future;

- team learning - create a new form of shared learning and knowledge and collective thinking skills; and

- system thinking - develop the ability to see 'wholes rather than individual parts' within an organization and understand how changes in one area affect the whole system.

This information becomes knowledge (and, hopefully, wisdom) for improving the work environment, improving performance, improving work processes, and achieving long-range goals that will make the organization successful (Gill, 2010). The Economic Commission of Africa (2010) believes that the development of organizational learning is a continuous innovation management, which has to be a top agenda of all public organizations in order to become high performance organizations.

Fenwick and Mcmillan (2005) opine that organizational learning is based on the notion of experience, whether individual or collective, although this does raise a difficult issue of 
whether an organization (in contrast to an individual) can be said to 'experience' something in any intelligible sense. A second assumption is that organizational learning produces change. That is, something has been learned, thus, the range of possible responses has grown, although we might add that the conclusion of "learning" could be that our existing actions are the best and, therefore, do not need to be changed at all: a point to which we will return. Thirdly, it is assumed that organizational learning is individual learning in a social environment - with others. Fourthly, learning is held to be organized, not at random, but is likely to have rules and an established pattern of acquiring knowledge, i.e., learning is directed (Fenwick and Mcmillan, 2005).

Organizational learning is multilevel (e.g., individual, group, organizational and inter-organizational), and it is, therefore, important that organizations consider the flow of learning across all levels (Crossan, Lane, White and Djurfeldt, 1995).

\section{Individual level}
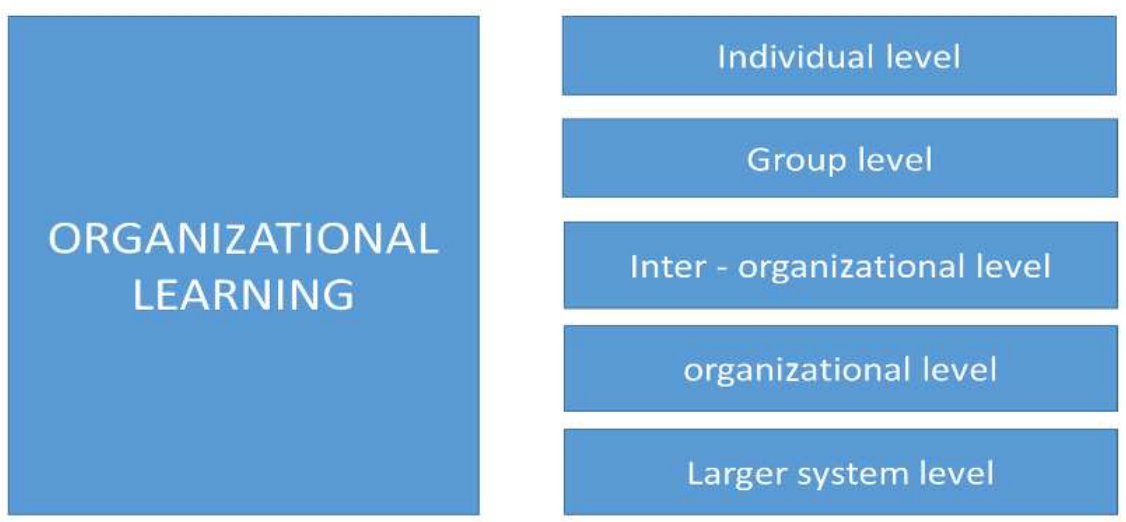

Fig. 2. The flow of learning across levels

Source: Welles (2011).

Garvin (1993) argues that there is a need for commitment to organizational learning, as continuous improvement requires a commitment to learning. An organization cannot improve without first learning something new. Solving a problem, introducing a product, and engineering a process requires seeing the world in a new light and acting accordingly. In the absence of learning, [organizations] - and individuals - simply repeat old practices". The Table below, as proposed by Garvin (1993), is used to assess the status of learning culture; it is an organizational learning self-audit to know if a nonprofit is doing what it can to learn and improve? This tool can be used to do a quick status check. The generated information is used in planning initiatives to improve organizational learning.

Table 4. Organizational learning self-audit

\begin{tabular}{|c|c|c|c|c|c|}
\hline Organizational learning statement & $\begin{array}{l}\text { Strongly } \\
\text { agree }\end{array}$ & Agree & $\begin{array}{l}\text { Neither agree } \\
\text { nor disagree }\end{array}$ & Disagree & $\begin{array}{l}\text { Strongly } \\
\text { disagree }\end{array}$ \\
\hline \multicolumn{6}{|l|}{$\begin{array}{l}\text { 1. This organization is constantly learning how to improve its own } \\
\text { performance. }\end{array}$} \\
\hline \multicolumn{6}{|l|}{$\begin{array}{l}\text { 2. Gathering feedback and reflecting on that information is commonly done } \\
\text { in this organization. }\end{array}$} \\
\hline \multicolumn{6}{|l|}{$\begin{array}{l}\text { 3. Managers who support individual and team learning are rewarded for } \\
\text { doing so. }\end{array}$} \\
\hline \multicolumn{6}{|l|}{$\begin{array}{l}\text { 4. We are constantly trying to learn how to have more effective meetings, } \\
\text { events and projects. }\end{array}$} \\
\hline \multicolumn{6}{|l|}{$\begin{array}{l}\text { 5. Experimentation and risk taking for the purpose of learning are supported } \\
\text { and not punished. }\end{array}$} \\
\hline \multicolumn{6}{|l|}{$\begin{array}{l}\text { 6. Physical spaces of offices and service areas are designed for optimum } \\
\text { learning among individuals and teams }\end{array}$} \\
\hline \multicolumn{6}{|l|}{$\begin{array}{l}\text { 7. Individuals understand what they need to learn in order to help the } \\
\text { organization be successful. }\end{array}$} \\
\hline \multicolumn{6}{|l|}{$\begin{array}{l}\text { 8. Individuals are encouraged to enhance their ability to help the } \\
\text { organization to be successful. }\end{array}$} \\
\hline $\begin{array}{l}\text { 9. Managers, coaches, and mentors help individuals to develop and } \\
\text { implement learning plans. }\end{array}$ & & & & & \\
\hline
\end{tabular}


Table 4 (cont.). Organizational learning self-audit

\begin{tabular}{|c|c|c|c|c|c|}
\hline Organizational learning statement & $\begin{array}{l}\text { Strongly } \\
\text { agree }\end{array}$ & Agree & $\begin{array}{c}\text { Neither agree } \\
\text { nor disagree }\end{array}$ & Disagree & $\begin{array}{l}\text { Strongly } \\
\text { disagree }\end{array}$ \\
\hline \multicolumn{6}{|l|}{$\begin{array}{l}\text { 10. Training programs are designed to help individuals to achieve their } \\
\text { learning goals. }\end{array}$} \\
\hline \multicolumn{6}{|l|}{$\begin{array}{l}\text { 11. Individuals receive frequent formal and informal feedback on their job } \\
\text { performance. }\end{array}$} \\
\hline \multicolumn{6}{|l|}{$\begin{array}{l}\text { 12. Individuals discuss with their supervisors what they need to learn to } \\
\text { improve their performance. }\end{array}$} \\
\hline \multicolumn{6}{|l|}{ 13. Team members help each other learn from their successes and failures } \\
\hline \multicolumn{6}{|l|}{ 14. Information is constantly shared among team members. } \\
\hline \multicolumn{6}{|l|}{$\begin{array}{l}\text { 15. Training programs are designed to help teams to achieve their learning } \\
\text { goals. }\end{array}$} \\
\hline \multicolumn{6}{|l|}{$\begin{array}{l}\text { 16. Teams are constantly developing new, more effective ways of working } \\
\text { as a group }\end{array}$} \\
\hline \multicolumn{6}{|l|}{$\begin{array}{l}\text { 17. The organization gathers feedback from its customers and stakeholders } \\
\text { for the purpose of learning. }\end{array}$} \\
\hline \multicolumn{6}{|l|}{$\begin{array}{l}\text { 18. Each department/unit informs other departments about what is being } \\
\text { learned. }\end{array}$} \\
\hline \multicolumn{6}{|l|}{$\begin{array}{l}\text { 19. The organization as a whole works at developing more effective ways to } \\
\text { solve problems and make decisions }\end{array}$} \\
\hline $\begin{array}{l}\text { 20. The organization is open to learning from the wider community that it } \\
\text { serves }\end{array}$ & & & & & \\
\hline
\end{tabular}

Source: Garvin (1993).

In Table 4, please indicate to what extent you agree with each of the statements listed below. Check the response option on the right that is closest to what you believe about your organization.

To achieve any institution objectives in terms of quality and quantity production, there is a need to embark on the constant training of employee.

\section{Conclusion and recommendations for future research}

In order to execute innovation in the public service, training and development of employees using the NPMT perspective is very important, whereby activities of public institutions would be likened to private business. Presently, many TWSs training and development for public officials have moved from being action-oriented to results oriented. The need for training and development should continue to be a top priority in the public service because of the rapid innovation and changes in the economic and social environment, especially in the work environment. Government departments are spending substantial amounts of money on training activities of officials. It is, therefore, necessary to develop new innovation and training approaches to face the challenges of negotiation with states and non-states actors at the global level. Training and development have a well-built relationship with globalization. Hence, continuous employee training and development is important in the development of individual and organizational performance.

Development and training of public employees will not only benefit departments, but will also inspire, challenge and advance the individual employee. As the initiator of innovations, employee training and development positioned within a wider strategic context of human resources management, i.e., global innovation management is essential for sustainable development in developing areas. Strategic staff education and development, at both individual and group levels, aim at benefitting both the organization and employees. According to Vemic (2007), the strategic procedure of employee training and development needs to encourage creativity, ensure inventiveness and shape the entire organizational knowledge that provides the organization with uniqueness and differentiates it from others. Vemic (2007) maintains that the logical sequence in knowledge creation and innovation equals to competitive advantage, as it applies to the private sector. He further states that it is not just about knowledge for the sake of it, but rather knowledge according to the needs, applicable knowledge, knowledge to create innovation and competitive advantage. Throughout the process of employee training and development, the management of human resources presents regular knowledge, innovation, established conditions for shared knowledge and experience exchange and positive behavior, thereby contributing to competitive advantage and satisfaction of all participants in the organization.

As Progressive International Limited (undated) explains: "Training can be a strong motivating factor for your staff, as it helps them to grow and gain new skills. This will help their performance at work and make them more marketable or employable". In order for training to be effective, it needs the full participation and commitment of employees at all 
levels. Within the framework of learning, it is not enough for workers to only add value to the organization based on his/her knowledge, but also has to receive knowledge to be efficient. Vemic (2007) and Rabie et al. (2011) believe that employee training and development does not imply only obtaining new knowledge, abilities and skills, but also the possibility to promote entrepreneurship, introduce employees to changes, encourage the changes of their attitude, introduce the employees to important business decisions and involve them actively in the process of decision-making.

The Commonwealth Association for Public Administration and Management (CAPAM, 2013) maintains that "within the complex structures, systems and processes of government, encouraging innovative thinking will require visionary leaders that can recognize emerging opportunities". Keen leadership and proficient management are needed to establish a culture of innovation, weigh the risks and benefits of new ideas, overcome the resistance to change, motivate staff to pursue solutions, and deliver real and tangible results for citizens. In line with this, leadership, management and innovationoriented service delivery solution in the public service are important.
The ever-changing globalized knowledge economy has created many challenges to the public sector to find and sustain sources of competitive advantage. The challenge of the public sector in TWSs to innovate includes a challenge to improve and extend practices for managing innovation and learning. Therefore, some public firms in developing states have developed successful strategies for such involvement in managing learning and innovation. Training and development of employees is a continuous process, which is the only significant and logical approach in the condition of knowledge obsolescence, steady changes and increasing the need for constant service innovations.

Therefore, an organization, which fails to recognize the presence of knowledge economy and does not transform into a learning organization on time, is gradually heading for self-destruction. Future research should examine learning and innovation practices in particular country. The research should be directed at identifying and refining measures for different forms or degrees of innovation capability at state/country level. This would provide a fuller picture of innovation within a country specific.

\section{References}

1. Acemoglu, Daron and Robinson, James A. (2012). Why Nations Fail: The origins of Power, Prosperity and Poverty. London: Profile Books.

2. Adamolekun, L. (1986). Politics and Administration in Nigeria. Ibadan, Nigeria: Spectrum Books.

3. Amusan, L. (2015). Challenges between Spoils and Meritocracy to Development: Post-apartheid South Africa Civil Service. Conference proceedings, South African Association of Public Administration and Management's $15^{\text {th }}$ annual conference with theme: Half-a-century of disciplinary existence-antecedence, evolution, scholarship, trends and issues, 21-24, April, Pretoria, South Africa.

4. Adams, R., Bessant, J. and Phelps, R. (2006). Innovation Management Measurement: A review, International Journal of Management Reviews, 8 (1), pp. 21-47.

5. Argyris, C. and Schon, D. (1978). Organizational Learning: A Theory of Action Perspective. McGraw-Hill Publisher.

6. Beeby, M. and Booth, C. (2000). Networks and Inter-Organizational Learning: A Critical Review, The Learning Organization, 7 (2), pp. 75-88.

7. Cohen, S. and Eimicke, W. (1996). Understanding and Applying Innovation Strategies in the Public Sector. American Society for Public Administration, 57th Annual National Conference. June 29-July 3, Atlanta Georgia.

8. Commonwealth Association for Public Administration and Management (CAPAM). (2013). Public Service Research and Innovation; A Quest for Sustained Service Delivery. Pretoria, South Africa, 4-6 March. Available at: http://www.palama.gov.za/MediaLib/Downloads/Downloads/CAPAM\%20Poster.pdf. Accessed on 29/4/14.

9. Corner, M. and Clawson, J. (2002). Creating a Learning Culture. Available at: http://agelesslearner.com/articles/lc_connerclawson_tc600.html. Accessed on 16/07/2013.

10. Crossan, M., Lane, H., White, R. and Djurfeldt, L. (1995). Organizational learning: dimensions for Developing a True Learning Culture. Progress International Ltd.

11. Dessler, G. et.al. (2011). Human Resource Management. Cape Town: Pearson.

12. Drezner, D.W. (2004). The Outsourcing Bogeyman, Foreign Affairs, pp. 22-34.

13. Drucker, P. (1992). Managing for the future. Oxford, England: Butterworth-Heinemann Publisher.

14. Economic Commission for Africa. (2010). Innovations and Best Practices in Public Sector Reforms: The Case of Civil Service in Ghana, Kenya, Nigeria and South Africa.

15. Fenwick, J. and McMillan, J. (2005). Organizational Learning and Public Sector Management: An Alternative View, Journal of Public Policy and Administration, Sage Publication, 20 (3), pp. $42-55$.

16. Fiol, C.M. and Lyles, M.A. (1985). Organizational learning, Academy of Management Review, 10 (4), pp. 803-813. 
17. Garcia, R. and Calantone, R. (2002). A critical look at technological innovation typology and innovativeness terminology: A literature review, Journal of Product Innovation, 19 (2), pp. 110-132.

18. Garvin, D. (1993). Building a Learning Organization, Harvard business review. Available at: https://hbr.org/1993/07/building-a-learning-organization.

19. Gill, S. (2010). Developing a Learning Culture in Non-Profit. USA: Sage Publication.

20. Gooderham, P.N., Grogaard, B. and Nordhaug, O. (2013). International Management: Theory and Practice. Cheltenham, UK and Northampton, MA, USA: Edward Elgar.

21. Greemhaus, J.H. et al. (2010). Career Management. London: Sage Publications.

22. Grier, S. (2014). Microsoft's Innovation Process Management Solution. IT Managers Inbox. Available at: http://itmanagersinbox.com/230/microsofts-innovation-process-management-solution/. Accessed on 7/5/14.

23. Kanter, R. (1983). The change masters: Corporate entrepreneurs at work. London: Routledge.

24. Kline, S.J. and Rosenberg, N. (1986). An Overview of Innovation. In The Positive Sum Strategy: Harnessing Technology for Economic Growth.

25. Lawson, B. and Samson, D. (2001). Developing Innovation Capability in: A Dynamic Capabilities Approach, International Journal of Innovation Management, 5 (3), pp. 377-400.

26. Little, A. (2001). The Innovative Company: Using Policy to Promote the Development of Capacities for Innovation. Final Report to Participating Governments. UK: Cambridge.

27. Livingstone, C. (2000). Innovation lecture. Sydney: Warren Centre.

28. Maccoby, M. (2003). The Seventh Rule: Creating a Learning Culture. Research Technology Management, 43 (3), pp. 59-60. Available at: http://www.maccoby.com/Articles/SeventhRule.shtml. Accessed on 7/5/2014.

29. Mathews, J.H. (2003). Knowledge Management and Organizational Learning: Strategies and Practices for Innovation, Organizational Learning and Knowledge, 5th International Conference.

30. Mazzucato, M. (2015). The Innovative State: Government Should Make Markets, Not Just Fix Them, Foreign Affairs, pp. 61-68.

31. Mbeki, M. (2009). Architects of Poverty: Why African Capitalism Needs Changing. Johannesburg: Picador Africa.

32. Mello, D.M. (2013). Affirmative action, employment equity and managing diversity. In DM Mello (ed.), Managing Human Capital in the Public Sector. Pretoria: van Schaik, pp. 53-68.

33. Mezue, B.C. et al. (2015). The Power of Market Creation: How Innovation can Spur Development, Foreign Affairs, pp. 69-76.

34. Microsoft. (2009). Innovation process management. Project Conference, Phoenix. Available at: http://www.microsoft.com/project/en-us/project-2007-process-management.aspx. Accessed on 1/15/2013.

35. Progressive International Limited. (Undated). Developing a True Organization Learning Culture. Available at: http://www.sefip.gov.uk/pdf/marketplace/Developing_a_true_organizational_learning_culture.pdf. Accessed on 6/5/14.

36. Quinn, J.B., Jordan, B.J. and Zien, K.A. (1997). Innovation explosion: using intellect and software to revolutionize growth strategies. New York: Free Press.

37. Rabie, B., Cloete, F. and Wissink, H. (2011). Policy education and training. In Fanie Cloete and Christo de Coning (eds.), Improving Public Policy: Theory, practice and results. Pretoria: Van Schaik Publishers, pp. 276-291.

38. Senge, P. (1990). The Fifth Discipline; the art and practice of the organization. New York: Currency Doubleday.

39. Trebilcock, M.J. and Prado, M.M. (2011). What Makes Poor Countries Poor? Institutional Determinants of Development. Cheltenham, UK and Northampton, MA: Edward Elgar.

40. Vemic, J. (2007). Employee Training and Development and the Learning Organization. Economics and Organization series, 4 (2), pp. 209-216.

41. Welles, L. (2011). Innovation and the role of Organizational Learning. Available at: http://hettyvanemmerik.com/ Teaching/Best_Chapter_Example_-_Innovation_and_the_role_of_OL_by_Lidy_Welles.pdf. Accessed on 2/5/14.

42. Zubane, P. (2011). Alternative Service Delivery Models for the South African Public Service for the Year 2020. A Master thesis. University of Stellenbosch. 